\title{
Electrochemiluminescence immunoassay for progesterone by using a heterologous system in plasma bovine
}

\author{
A. Ayad ${ }^{1,2}$, M. Iguer Ouada ${ }^{1}$ and H. Benbarek ${ }^{2,3}$
}

1. Department of Environment and Biological Sciences, Faculty of Life and Nature Sciences, University A. Mira, 06000 , Bejaia, Algeria; 2. Laboratory of Research on Local Animal Products, Veterinary Institute, Ibn Khaldoun University, 14000, Tiaret, Algeria; 3. Department of Agricultural Sciences, Faculty of Life and Nature Sciences, University M. Istambouli, 29000, Mascara, Algeria.

Corresponding author: A. Ayad, email: hanine06@gmail.com, abdelhanine.ayad@univ-bejaia.dz, MIO: imokrane@gmail.com, HB: benbarekh@yahoo.com

Received: 12-05-2014, Revised: 27-07-2014, Accepted: 02-08-2014, Published online: 21-08-2014

doi: 10.14202/vetworld.2014.610-613 How to cite this article: Ayad A, Iguer Ouada M, Benbarek H (2014) Electrochemiluminescence immunoassay for progesterone by using a heterologous system in plasma bovine, Veterinary World 7(8): 610-613.

\begin{abstract}
Aim: The present study describes the use of electrochemiluminescence (ECL) immunoassay method with specific kit human progesterone for measuring plasma progesterone in cattle.

Materials and Methods: Nine Holstein-Friesian females were selected and artificially inseminated (AI). Blood samples were collected from the coccygeal vessels into tubes containing EDTA at day $0(n=5$, the control group) and day 90 ( $n=4$, diagnosed pregnant by rectal palpation) after AI. The day of AI was considered as day 0 for the calculation of pregnancy day. The samples were immediately centrifuged $(15 \mathrm{~min}$ at $1500 \times \mathrm{g})$, and the plasma was stored at $-20^{\circ} \mathrm{C}$ until assay. The assay of progesterone was carried out by a method of competition immunological type in heterogeneous phase. The antibodies of capture and revelation are monoclonal specific to progesterone of human origin.
\end{abstract}

Results: The progesterone (P4) concentration in the whole female was physiological. The results of inter- and intraassay coefficients of variation were $16.6 \%$ and $6.7 \%$, respectively. The values of accuracy and parallelism obtained were satisfactory.

Conclusion: The preliminary results show clearly that human progesterone ECL kit can be used to measure P4 in plasma bovine.

Keywords: assay, cow, electochemiluminescence, progesterone.

\section{I ntroduction}

For over 40 years, progesterone (P4) has been used to monitor ovarian, estrous detection and pregnancy in the cattle. The determination of the ovulation time is of a major importance in the reproduction management in the cattle, as it indicates the most appropriate period for mating or insemination [1]. Similarly, it is indicated that the assay of progesterone constitutes an excellent tool in the embryonic mortalities investigations [2].

The essential role of $\mathrm{P} 4$ in the maintenance of gestation is known since a long time. It was the basis of the first methods developed for hormonal assay. Different types of progesterone assay (radio-, enzyme, fluorescent immunoassay) are currently used to determine the concentration of progesterone in the blood, whole milk and milk fat as a biomarker to detect the estrous cycle and to diagnosis early pregnancy in bovine [3-7]. Indeed, it was shown that there exists a parallelism between the rate of plasmatic and milk progesterone [8].

The radioimmunoassay (RIA) method has several limitations inherent to the use of radioactive isotopes.

Copyright: The authors. This article is an open access article licensed under the terms of the Creative Commons Attributin License ( http:// creative commons.org/licenses/by/2.0) which permits unrestricted use, distribution and reproduction in any medium, provided the work is properly cited.
Similarly, the problem of enzyme immunoassay (EIA) techniques might be due to the interference in the assay of sample constituents rather than to the hormone to be measured [9]. Electrochemiluminescence (ECL) method is a form of chemiluminescence in which the light emitting chemiluminescent reaction is preceded by an electrochemical reaction [10]. This method is currently used as an advanced technique for human clinical analysis.

Therefore, the present study was designed to test the usefulness of ECL immunoassay method using a specific kit human Progesterone for measuring plasma progesterone in cattle.

\section{Materials and Methods}

\section{Ethical approval}

The study protocol was approved by the Ethical Committee of the University A. Mira, Bejaia (Algeria).

Nine Holstein-Friesian females (mixed ages and parity) were selected and artificially inseminated (AI). Blood samples were collected from the coccygeal vessels into tubes containing EDTA at day $0(n=5$, control group) and day $90(\mathrm{n}=4$, diagnosed pregnant by rectal palpation) after AI. The day of AI was considered as day 0 for the calculation of pregnancy day. The samples were immediately centrifuged $(15 \mathrm{~min}$ at $1500 \times \mathrm{g}$ ), and the plasma was stored at $-20^{\circ} \mathrm{C}$ until assay [11]. 
The assay of progesterone was carried out by a method of competition immunological type in heterogeneous phase. It is revealed by ECL (substrate: ruthenium) on the automat. The antibodies of capture and revelation are monoclonal specific to progesterone of human origin. The total duration of the assay is $18 \mathrm{~min}$.

In the first incubation, $30 \mu \mathrm{l}$ of plasma sample was added to a mixture of the antibody anti-progesterone labeled with biotin and the peptide-progesterone labeled with ruthenium. In the second incubation, the streptavidin was added in the reactional well. The immunological complex was fixed at the solid phase by a complex streptavidin-biotin. The quantity of progesterone linked at the solid phase is inversely proportional to the progesterone concentration in the sample. The reactional mixture was transferred in the measuring cell. The micro-particles were maintained in the electrode level by a magnet. The elimination of the free fraction was carried out with a washing buffer. A potential difference applied to the electrode starts the production of luminescence that was measured by a photomultiplier (Figure-1).

The estimated dose of measurement extends from 0.03 to $60 \mathrm{ng} / \mathrm{ml}$. Parameters of validation including minimal limit of detection (MDL), reproducibility (coefficient of variation inter- and intra-assay), accuracy and parallelism were taken into consideration in this study.

\section{Results and Discussion}

The early diagnosis of pregnancy is of a particular importance in the economics of bovine breeding. Indeed, the delay of fecundation affects considerably the profitability of the bovine exploitation. The progesterone is a hormone of the reproduction produced by the corpus luteum (CL) and the placenta at advanced stages of gestation.

The P4 concentration (mean \pm standard error) determined in plasma samples from bovine females are represented in Table-1. The control group

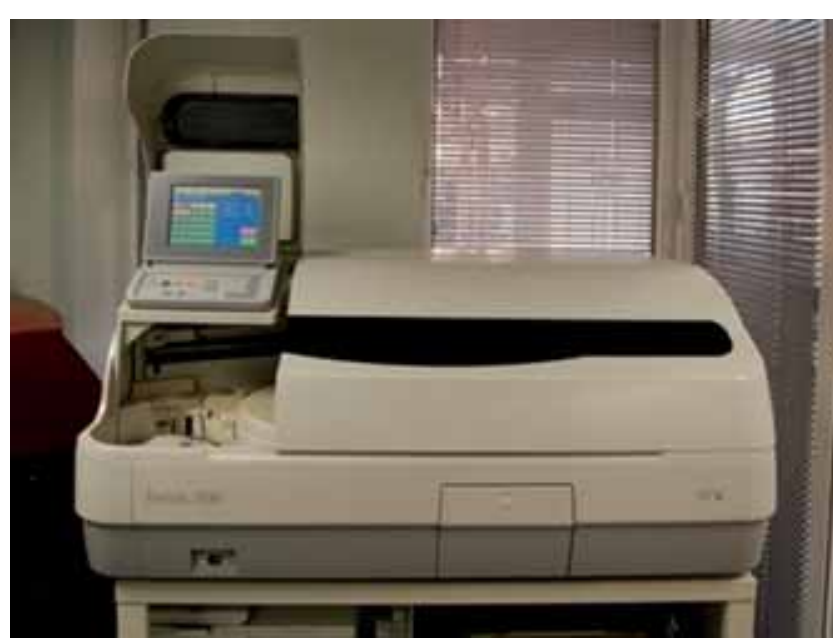

Figure-1: Photo represent measurement instrument (Elecsys 2010). shows very low progesterone concentrations in plasma $(0.17 \pm 0.06 \mathrm{ng} / \mathrm{ml})$. This concentration reveals the absence of a secretion luteal in the control group $(<1 \mathrm{ng} / \mathrm{ml})$. Note that $\mathrm{P} 4$ concentrations $\geq 1 \mathrm{ng} / \mathrm{ml}$ indicate a functional $\mathrm{CL}$ and concentrations $<1 \mathrm{ng} / \mathrm{ml}$ indicate a lack of functional CL or noncyclicity $[12,13]$. In the pregnant females, the concentrations of P4 obtained by ECL method were very high $(9.3 \pm 3.6 \mathrm{ng} / \mathrm{ml})$. According to Shamsuddin et al. [7], these results confirm the late diagnosis of gestation by rectal exploration in inseminated females (2-3 months post-AI). The concentrations of $\mathrm{P} 4$ measured by ECL in the present study would have been produced by the $\mathrm{CL}$. This is the major source of P4 during a large pregnancy period, i.e., until day 200 [14].

The MDL corresponds to the progesterone low concentration, which can be distinguished from zero. The MDL gave by using ECL assay was $0.03 \mathrm{ng} / \mathrm{ml}$. In the present study, the progesterone values found in the inseminated females were all higher than the MDL. The MDL of P4 plasmatic measured by RIA method was and $0.04 \mathrm{ng} / \mathrm{ml}$ [15], and $0.38 \mathrm{ng} / \mathrm{ml}$ by the enzyme-immunoassay method [16]. In other study, the MDL was very low $(0.01 \mathrm{ng} / \mathrm{ml})$ using a radio or fluorescent immunoassay $[17,18]$. Ghillis et al. [19] have validated a system immunoassay, biosensor-based of bovine P4 with a very high MDL $(3.56 \mathrm{ng} / \mathrm{ml})$. The MDL calculated in the present study was very sensitive, which could be due to the use of the monoclonal antibodies.

The reproducibility was evaluated with bovine plasma. The coefficients of variation (CV) inter- and intra-assay obtained were respectively $16.6 \%$ and $6.7 \%$ (Table-2). The test of reproducibility inter- and intraassay of the system ECL assay is satisfactory. The CV of $7.8-9.4 \%$ and $5.8-8.5 \%$ inter- and intra-assay of plasmatic P4 were recorded by RIA method [20-22]. In 2007, Bayemi et al. [23] have also obtained the nearly equal values of $\mathrm{CV}$ inter- and intra-assay of bovine serum (12.6 and $7.1 \%$, respectively) using an immuno-enzymatic assay containing human reagents.

The test of dilution (parallelism) was assessed by serially dilution $(1 / 1,1 / 2$ and $1 / 4)$ with serum of a

Table-1: P4 concentrations (mean $\pm \mathrm{SE}$ ) obtained by ECL systems in non-pregnant and pregnant females.

\begin{tabular}{lc}
\hline & $\begin{array}{c}\text { P4 concentration } \\
\text { (mean } \pm \text { SE } \mathbf{n g} / \mathbf{~ m l )}\end{array}$ \\
\hline Non-pregnant females $(n=5)$ & $0.17 \pm 0.06$ \\
Pregnant females $(n=4)$ & $9.3 \pm 3.6$ \\
\hline
\end{tabular}

$\mathrm{ECL}=$ electrochemiluminescence, $\mathrm{SE}=$ standard error

Table-2: Intra and inter-assay CV of P4-ECL system.

\begin{tabular}{lcc}
\hline & $\begin{array}{c}\text { P4 Concentration } \\
\text { ( mean } \pm \text { SE } \mathbf{~ n g} / \mathbf{~ m I )}\end{array}$ & CV (\%) \\
\hline Intra-assay $(\mathrm{n}=4)$ & $0.58 \pm 0.09$ & 6.7 \\
Inter-assay $(\mathrm{n}=5)$ & $10.49 \pm 0.71$ & 16.6 \\
\hline
\end{tabular}

$\mathrm{CV}=$ coefficients of variation, $\mathrm{SE}=$ standard error 
pregnant cow containing relatively high $\mathrm{P} 4$ concentration. The results show clearly that the concentrations P4 obtained are parallel, with rates of recovery ranging from $102 \%$ to $110 \%$. We can conclude that the test of dilution of system ECL is very satisfactory. As for the accuracy, the results obtained by the technique used are also satisfactory. The percentages of covering obtained were slightly high (111-117\%). Nevertheless, these results of accuracy always remain acceptable. In 1987, Eckersall and Harvey [24] validated a kit ELISA of bovine progesterone, which is used in the species' equine, ovine and canines. Moreover, Bayemi et al. [23] had validated a human P4 EIA kit for use on serum of cattle. Many kits are continuously developed for human laboratories. When they are available, they could be used for measuring P4 levels in bovine because the progesterone is not specific to define species.

\section{Conclusion}

The preliminary results show clearly that the human progesterone ECL kit can be used to measure progesterone in plasma bovine. However, future detailed and comparative studies are needed to validate the assay system and consolidate the approach proposed.

\section{Authors' Contributions}

AA designed, performed the research and drafted the manuscript. MI-O and HB reviewed the manuscript. All authors read and approved the final manuscript.

\section{Acknowledgments}

Dr. A. Ayad wishes to thank Dr. Moualek (Laboratory of Human Clinical Analyze, Bejaia, Algeria) for providing the reagents and his technical assistance (Elecsys 2010). The authors thank M. Harrats Ch. (University of Ain-Temouchent, Algeria) for the English correction. This study was supported by Laboratory of Research on Local Animal Products grant (University of Tiaret). The authors declare that any person of Roche Diagnositcs was not included in the study either directly or indirectly.

\section{Competing I nterests} interests.

The authors declare that they have no competing

\section{References}

1. Ozturk, O.A., Cirit, U., Baran, A. and Ak, K. (2010) Is doublesynch protocol a new alternative for timed artificial insemination in anestrous dairy cows. Theriogenology, 73(5): 568-576.

2. Celi, P., Merlo, M., Barbato, O. and Gabau, G. (2012) Relationship between oxidative stress and the success of artificial insemination in dairy cows in a pasture-based system. Vet. J., 193(2): 498-502.

3. Trapiella-Alfonso, L., Costa-Fernández, J.M., Pereiro, R. and Sanz-Medel, A. (2011) Development of a quantum dot-based fluorescent immunoassay for progesterone determination in bovine milk. Biosens. Bioelectron., 26(12): 4753-4759.

4. Bridges, G.A., Mussard, M.L., Burke, C.R. and Day, M.L. (2010) Influence of the length of proestrus on fertility and endocrine function in female cattle. Anim. Reprod. Sci., 117(3-4): 208-215.

5. Kendall, N.R., Flint, A.P.F. and Mann, G.E. (2009) Incidence and treatment of inadequate postovulatory progesterone concentrations in repeat breeder cows. Vet. J., 181(2): 158-162.

6. Faustini, M., Battocchio, M., Vigo, D., Prandi, A., Veronesi, M.C., Comin, A. and Cairoli F. (2007) Pregnancy diagnosis in dairy cows by whey progesterone analysis: An ROC approach. Theriogenology, 67(8): 1386-1392.

7. Shamsuddin, M., Bhuiyan, M.M.U., Chanda, P.K., Alam, M.G.S. and Galloway, D. (2006) Radioimmunoassay of milk progesterone as a tool for fertility control in smallholder dairy farms. Trop. Anim. Health Prod., 38(1): 85-92.

8. Delahaut, Ph., Beckers, J.F. and Ectors, F. (1978) Early pregnancy diagnosis in different animal species. Ann. Méd. Vét., 122: 205-208.

9. Van de Wiel, D.F.M. and Koops, W. (1986) Development and validation of an enzyme immunoassay for progesterone in bovine milk or blood plasma. Anim. Reprod. Sci., 10: 201-213.

10. Richeter, M.M. (2004) Electrochemiluminescence (ECL). Chem. Rev., 104(6): 3003-3036.

11. Delahaut, Ph., Beckers, J.F. and Ectors, F. (1979) Effect of sodium azide on progesterone degradation in bovine blood samples. Ann. Méd. Vét., 123: 567-572.

12. Karen, A.M. and Darwish, S.A. (2010) Efficacy of ovsynch protocol in cyclic and acyclic Egyptian buffaloes in summer. Anim. Reprod. Sci., 119(1-2): 17-23.

13. Kayacik, V., Salmanoglu, M.R., Polat, B. and Özlüer, A. (2005) Evaluation of the corpus luteum size throughout the cycle by ultrasonography and progesterone assay in cows. Turk. J. Vet. Anim. Sci., 29: 1311-1316.

14. Chew, B.P., Erb, R.E., Fessler, J.F., Callahan, C.J. and Malven, P.V. (1979) Effects of ovariectomy during pregnancy and of prematurely induced parturition on progesterone, estrogens, and calving traits. J. Dairy Sci., 62(4): 557-66.

15. Shrestha, H.K., Beg, M.A., Siddiqui, M.A.R. and Ginther, O.J. (2010) Dynamic progesterone responses to simulation of a natural pulse of a metabolite of prostaglandin F(2alpha) in heifers. Anim. Reprod. Sci., 118(2-4): 118-123.

16. Boland, M.P., Foulkes, J.A., MacDonnell, H.F. and Sauer, M.J. (1985) Plasma progesterone concentrations in superovulated heifers determined by enzymeimmunoassay and radioimmunoassay. Br. Vet. J., 141(4): 409-15.

17. Vasconcelos, J.L.M., Jardina, D.T.G., Sá Filho, O.G., Aragon, F.L. and Veras, M.B. (2011) Comparison of progesterone-based protocols with gonadotropin-releasing hormone or estradiol benzoate for timed artificial insemination or embryo transfer in lactating dairy cows. Theriogenology, 75(6): 1153-1160.

18. Beltman, M.E., Roche, J.F., Lonergan, P., Forde, N. and Crowe, M.A. (2009) Evaluation of models to induce low progesterone during the early luteal phase in cattle. Theriogenology, 72(7): 986-992.

19. Ghillis, H.E., Gosling, J.P., Sreenan, J.M. and Kane, M. (2002) Development and validation of a biosensor-based immunoassay for progesterone in bovine milk. J. Immunol. Methods, 267(2): 131-138.

20. Pulley, S.L., Wallace, L.D., Mellieon, H.I. Jr. and Stevenson, J.S. (2013) Ovarian characteristics, serum concentrations of progesterone and estradiol, and fertility in lactating dairy cows in response to equine chorionic gonadotropin. Theriogenology, 79(1): 127-134.

21. Tamadon, A., Kafi, M., Saeb, M., Mirzaei, A. and Saeb, S. (2011) Relationships between insulin-like growth factor-I, milk yield, body condition score, and postpartum luteal activity in high-producing dairy cows. Trop. Anim. Health Prod. 43(1): 29-34. 
22. Ayad, A., Sousa, N.M., Sulon, J., Hornick, J.L., Watts, J., Lopez-Gatius, F., Iguer-Ouada, M. and Beckers, J.F. (2007) Influence of progesterone concentrations on secretory functions of trophoblast and pituitary during the first trimester of pregnancy in dairy cattle. Theriogenology, 67(9): 1503-11.

23. Bayemi, P.H., Nsongka, V.M., Perera, B.M., Cavestany, D. and Webb, E.C. (2007) Validation of a human progesterone enzyme immunoassay (EIA) kit for use on serum of cattle in Cameroon. Trop. Anim. Health Prod., 39(5): 335-8.

24. Eckersall, P.D. and Harvey, M.J. (1987) The use of a bovine plasma progesterone ELISA kit to measure progesterone in equine, ovine and canine plasmas. Vet. Rec., 120(1): 5-8.

$* * * * * * * *$ 